\title{
Skrifbeskouing en die Nederlandse Geloofsbelydenis
}

\author{
GC Velthuysen
}

\section{INLEIDEND}

Die uitgangspunt van hierdie studie, is dat die Nederlandse Geloofsbelydenis, soos enige ander dokument, beoordeel moet word as 'n geskrif van sy tyd. Hierdie uitgangspunt wil nie vanuit die staanspoor die waarde of gesag van die belydenisskrif relativeer nie, maar moet geld as die vasstelling van die feit dat dit ' $n$ aard het wat nie losgemaak kan word van die situasie waarin dit ontstaan het nie. Daarom sal enige poging om hierdie belydenisskrif voor te stel as 'n tydlose dokument, die belydenis as sodanig 'n onreg aandoen. (En dieselfde geld ook mutatis mutandis ten opsigte van die ander twee.)

Die belydenis van die kerk het 'n dubbele grond - innerlik én uiterlik. Ons kan praat van innerlike drang en uiterlike druk. Die innerlike drang ontspring aan die geloof self. Dit lê in die aard van die geloof dat dit tot spreke dring. Die geloof is nie stom nie; dit het 'n stem wat gehoor moet word, dit kan nie stilgemaak word nie. Die uiterlike druk, aan die ander kant, is afkomstig van die weerstand waarteen die geloof stuit. Die geloof kan stuit òf teen openlike vyandskap en teenspraak, òf teen verdraaiing en versluiering van die geloofswaarheid, òf teen totale ongeïnteresseerdheid en swye. Die belydenis sal met die aard van die weerstand rekening moet hou as dit enigsins relevant wil wees. Daarom kan dus gesê word dat die belydenis deur twee kragte gevorm word: Die geloof dring tot belydenis; die aard van die weerstand waarteen die geloof stuit, bepaal die karakter en strekking van die belydenis. Hierdeur word egter nie gesê dat die situasie die inhoud van die belydenis bepaal nie. Die inhoud is geloofsgoed. Die meeste wat beweer word, is dat die strekking van die belydenis medebepaal word deur die omstandighede waarin die kerk hom bevind.

Die drie belydenisskrifte van die kerk kan geld as 'n pragtige illustrasie van hierdie stelling. Die kerk sou byvoorbeeld nie die Leerreëls van Dordrecht gehad het, as dit nie was vir die stryd teen die Armeniane nie, en die Heidelbergse Kategismus én die Nederlandse Geloofsbelydenis sou baie anders daaruit gesien het, as die 
weerstand destyds van die Pentekostalisme of die kommunisme, pleks van die kant van Rome gekom het.

Die implikasie van hierdie feit, is dat die belydenisskrifte van die kerk geëksegetiseer moet word. Daar moet deurgevors word na wat die opstellers, in daardie bepaalde omstandighede, wou deurgee as hulle wesenlike geloof. Op sy beurt beteken dit dat die woorde en nuanses van die belydenisskrifte nie beklee moet word met ewigheidswaarde nie. Dit is denkbaar dat dieselfde waarheid destyds, met die gebruikmaking van ander woorde en nuanses, ter sprake gebring kon gewees het. Die verantwoordelike omgang met die belydenisskrifte skuil dus nie in die heiliging van die letter daarvan nie, maar in die uitlig van die wesenlike geloofswaarheid wat daarin verwoord is.

\section{DIE SKRIFBESKOUING VAN DIE NEDERLANDSE GELOOFSBELYDENIS VOLGENS GEREFORMEERDE INTERPRETASIE}

Vir sover as wat daar by die Nederlandse Geloofsbelydenis sprake is van ' $n$ Skrifbeskouing, word dit aangetref in artikels 2 tot 7.

In artikel 2 is daar natuurlik, streng gesproke, nog nie sprake van die Heilige Skrif nie. Hier word daar nog gepraat oor die middele waardeur God geken word en dan word daar onder andere klem gelê op die feit dat Hy Homself aan ons bekend maak "deur sy heilige en goddelike Woord". In artikel 3 word dan verder oor hierdie Woord gepraat: Dit is hierdie Woord wat die heilige mense van God, gedrywe deur die Heilige Gees, gespreek het. Daarna is dit op bevel van God op skrif gestel, en vandaar dra hierdie geskrifte die betiteling van heilige en goddelike geskrifte. Artikel 5 gee uitdrukking aan die geloof van die kerk dat hierdie geskrifte die enigste norm en reël vir die geloof is, en dat alles wat daarin bevat is, sonder twyfel geglo word. Dit word deur die kerk bely, nie omdat die kerk hierdie geskrifte aanneem nie, maar omdat die Heilige Gees getuig dat hulle van God is, en omdat hulle die bewys van hulle betroubaarheid in hulleself het. In artikel 7 word dan stilgestaan by die geloofsuitspraak dat die leer wat in hierdie Skrifte bevat word, volmaak en in alle opsigte volkome is en dat daar dus niks bygevoeg of weggeneem moet word nie.

Dit dan, in 'n neutedop, wat die kerk in hierdie paar artikels bely. Voordat daar oorgegaan word tot die eksegese hiervan, sal dit ver- 
helderend wees om na te gaan wat die gereformeerde tradisie hiervan gemaak het.

Die belangrikste faset waarop die aandag hier gevestig kan word, is dat in hierdie skool van denke, die Heilige Skrif geheel en al gelykgestel word aan die Woord van God. Heeltemal tereg stel Ridderbos": "Wat niet zelden het isolement van de (confessioneel) gereformeerde schriftbeschouwing genoemd wordt is daarin gelegen, dat zij een verband van identiteit legt tussen het Woord Gods en de geschreven Bijbel." Hulle lê hierdie verband van identiteit omdat die Bybel self van die bestaan daarvan getuig. Bavinck ${ }^{2}$ stel dit as volg: "De Schrift (dient) zichzelve (aan) als het Woord Gods en de gemeente des Heeren in alle eeuwen (heeft) haar als zodanig erkend." Veral Polman ${ }^{3}$ lewer 'n hartstogtelike pleidooi vir die aanvaarding van die "selfgetuienis" van die Skrif met as konklusie: "De Heilige Schrift is het onfeilbaar geïnspireerde Woord Gods, dat absolute autoriteit heeft." Sy gevolgtrekking uit Jesus se gebruik van die $\mathrm{Ou}$ Testament en sy verwysings na die gesag daarvan, is dat Jesus aan die hele Ou Testament, en tot in die fynste onderdele daarvan, absolute gesag toegeken het.

So 'n standpunt maak dit onvermydelik en noodwendig dat die algehele en totale onfeilbaarheid van die Skrifte geleer sal word. As Jesus absolute gesag aan selfs die kleinste onderdeeltjie van die Skrif toeken, beteken dit dat die Skrif betroubaar moet wees in alle sake wat hy vermeld; m.a.w. nie net in leerstellige sake nie, maar ook wat historiese, argeologiese, geologiese, aardrykskundige en naturwetenskaplike aangeleenthede betref.

Die gevolg hiervan is uiteraard dat enige vorm van kritiese omgang met die Skrif taboe is: "Want wie zijn leer van de Schrift afhankelijk maakt van het historisch onderzoek naar hare wording en structuur, begint reeds met het getuigenis der Heilige Schrift te verwerpen en staat dus niet meer in het geloof aan de Schrift. Hij meen de leer van de Schrift beter te kunnen opbouwen uit eigen onderzoek dan ze in den gelove te ontlenen aan de Schrift; hij stelt zijn eigen gedachten in plaats van en boven die der Schrift"

Polman ${ }^{5}$ lewer, deur sy simpatieke hantering van die standpunt van die ekstreme Roomse(!) ortodoksie, genoegsaam bewys daarvan dat hy die gevoltrekkings van die kritiese wetenskap verwerp: Moses het self die eerste vyf boeke van die Bybel geskryf, die eerste drie hoofstukke van Genesis is ware geskiedskrywing, één skrywer, nl. Jesaja, is verantwoordelik vir die hele boek Jesaja, ens. Die Bybel 
word dus gesien as 'n groot oorsigtelike eenheid, waarvan elke letter geinspireer is, en wat as geheel en tot in die fynste besonderhede, absolute gesag het. En dit, so word met groot stelligheid beweer, is die standpunt van die belydenis, en elke poging om dit te ontken, is 'n verkettering daarvan.

\section{WAT WOU DIE NEDERLANDSE GELOOFSBELYDENIS SÊ?}

Dit mag wees dat bogenoemde standpunt die opvattings van die vadere noukeurig weergee. Daar moet egter onmiddellik in gedagte gehou word dat hulle nie moeite sou hê met die wêreldbeeld van die Skrif nie, aangesien dit nog grotendeels hulle eie was. Ook wat betref skriftuurlike uitsprake op historiese of natuurwetenskaplike gebied sou hulle vrede hê, aangesien die kennis, wat feitelike onjuisthede in die Skrifte sou raaksien, by hulle nog ontbreek het. 'n Uitspraak soos dié van Levitikus 11:5 en 6 byvoorbeeld, word eers 'n probleem wanneer jy tot die insig kom dat 'n haas en 'n klipdas nié herkou nie, maar dat dit net lýk of hulle herkou en dat die uitspraak van Levitikus gevolglik steun op foutiewe waarneming. Sodanige wetenskaplike insig het die vadere nog nie gehad nie - en gevolglik was hierdie sake vir hulle nie problematies nie. Daarom het hulle ook nie probleme gehad met die feitelike korrektheid van die Skrifte nie. Daarom is dit ' $n$ probleem wat by hulle nie eers ' $n$ rol speel nie. Die reformatore se uitsprake oor die Skrif het net één doel voor oë gehad, en dit was om, teenoor die sakramentalisme van Rome, alle nadruk op die Woord as genademiddel te laat val.

Daarom vind ons in die belydenis so 'n sterk klemlegging op die feit dat die Skrifte hulle oorsprong nie in die mens het nie, maar in die Heilige Gees (art 3). Daar word egter nie detailuitsprake gemaak oor hoé die Heilige Gees verantwoordelik is vir die totstandkoming van die Skrifte nie. Daar word volstaan met die aanhaling van 2 Petrus 1:21, waarvolgens die Heilige Gees die heilige mense van God gedryf het om te spreek, en die uitspraak dat God bepaalde mense beveel het om hierdie geopenbaarde Woord op skrif te stel. 'n Groots-opgesette inspirasieleer word dus nie gevind nie. Daar sou 'n saak uitgemaak kon word vir die stelling dat die ganse tradisionele inspirasieleer agter die formulering van die belydenis skuil, maar uit die formulering as sodanig is dit nie af te lei nie.

Vervolgens vind ons, as gevolg van die feit dat Rome die standpunt huldig dat die Skrif uit die kerk kom en die kerk dus die omvang daarvan bepaal, in die belydenis ' $n$ klemlegging op die feit 
dat die Heilige Gees die kerk daarvan oortuig dat hierdie geskrifte van God is. Dit is in hierdie konteks wat daar van die selfgetuienis van die Skrif gepraat word, wanneer bygevoeg word dat hy die bewys van sy goddelike oorsprong in homself het. Ook hier het ons dus nie te make met 'n uitgebreide leer oor die Skrif as sodanig nie, maar hoogstens net 'n vasstelling van die feit dat die Skrif nie gesag het omdat die kerk dit aan hom toeken nie, maar omdat hy dit in homself het.

Vanuit artikels 6 en 7 word dit vervolgens duidelik watter gesag deur die belydenis in die Skrif raakgesien en bely word. Die Skrif het gesag omdat dit reël van die geloof is, sy getuienis bevestig die geloof en die Christelike godsdiens en dit leer alles wat die mens moet glo om gered te word genoegsaam. Ook hierdie uitspraak van die belydenis is kennelik gemik teen Rome - Rome wat aan die besluite van konsilies, aan die tradisie en aan die uitsprake van die pouse, net soveel gesag as aan die Skrif toeken.

Dit is duidelik dat dit wat die belydenis aangaande die Heilige Skrif bely die strekking het om die Skrif veilig te stel as regula fidei, sonder om andersins ' $n$ uitgewerkte leer van die Skrif aan te bied, of oor elke uitspraak van die Skrif ' $n$ oordeel te vel. Vanuit die belydenis as sodanig, is daar in elk geval nie genoeg grond vir Polman ${ }^{6}$ se stelling dat die kerk met hierdie belydenis sê dat hy alles wat in die Skrif bevat word sonder enige twyfel glo nie. Wanneer die belydenis hierdie woorde wel gebruik (artikel 5), staan dit in die konteks van die Christelike leer wat dien as reël van die geloof. Dit glo die kerk wel onvoorwaardelik, maar hieruit is nie af te lei dat die kerk daarmee saam byvoorbeeld die dawidiese outeurskap van elke psalm wat sy naam dra, aanvaar nie, en ook nie dat hy hiermee bely dat Jona werklik in die buik van ' $n$ vis was nie. Al sou die opsteller van die belydenis dit geglo het, is dit in elk geval nie af te lei uit die formulering wat hy gebruik nie.

\section{KAN 'N KRITIESE SKRIFBESKOUING OP DIE NEDERLANDSE GELOOFSBELYDENIS GEBOU WORD?}

Dit is reeds hierbo aangedui dat wanneer die formulering van die belydenis noukeurig bekyk word, mens tot die gevolgtrekking moet kom dat die wesenlike van die belydenis dit is dat die Heilige Skrif sy ontstaan en gesag te danke het aan die Heilige Gees. Daar word nie gespekuleer oor hoé dit gebeur het nie, maar die feit word met 
groot stelligheid gestel. Naas hierdie vasstelling moet daar egter ook waardering wees vir die feit dat die belydenis ruimte laat vir die menslikheid van die Skrif. Dit is nie die Heilige Gees wat die goddelike Woord gespreek het nie - mense, gedrywe deur die Gees, het dit gespreek. Die Heilige Gees was ook nie die teboeksteller van die Woord nie - mense, onder die bevel van God, het dit geskryf. Aldus artikel 3.

Dit is natuurlik ook die klassiek-gereformeerde beskouing. Mens sou 'n karikatuur van hulle standpunt maak as jy dit nie vermeld nie. Mense hét die geopenbaarde Woord van God te boek gestel, maar hulle was hoogstens instrumente in die hand van die Gees - hulle kon iets van hulle persoonlikheid meegee - maar nie iets van hulle gebreke nie. Daar kan nie 'n gebrek of fout in die Skrif wees nie, want die Gees staan vader vir alles wat daarin geskryf is.

Nou is dit reeds meermale voldoende aangetoon ${ }^{7}$, dat die feitelike onfeilbaarheid van die Skrif (met ander woorde, die volkome historiese en feitelike juistheid), net met skouspelagtige breingimnastiek volhardend verdedig kan word. Die kritiese wetenskap het aangetoon dat so iets as die eenheid van die Skrif ' $n$ mite is; dat die klassieke reformatoriese slagspreuk sacra scriptura sui ipsius interpres, nie diensbaar kan wees in die sin dat teensprake en on-effenhede in die Skrif daarmee uit die weg geruim kan word nie en dat dit getuig van rasionalisme ${ }^{8}$ wanneer dit tog gepoog word. Die kritiese wetenskap wil egter nie die Bybel verkleineer of versimpel nie, "maar gee aan die eksegeet die geleentheid om die ryke prediking van die Bybel in sy nuanses en skakeringe te ontdek en met beskeie versigtigheid vir die prediking vrugbaar te maak"9. Die kritiese wetenskap verstaan die Bybel dus as prediking en die Bybelskrywers as getuies. Die vraag is of so 'n Skrifbeskouing nog gerym kan word met die uitspraak van die belydenis.

Hierbo is betoog dat die belydenis eintlik niks meer oor hierdie sake sê nie as dat die Heilige Skrif sy ontstaan en gesag te danke het aan die Heilige Gees. Daarby word ook klem gelê op die feit dat die Skrif nie los van, of sonder die werksaamheid van mense ontstaan het nie. Teenoor Rome word die goddelike inspirasie van die Skrif verdedig. By die moderne kritiese wetenskaplikes word, teenoor fundamentalistiese Bybelbeskouings, klem gelê op die menslikheid van die Skrif, sonder om daarmee noodwendig die geïnspireerdheid daarvan te loën. Selfs 'n radikale kritikus soos Barr, glo dat die Bybel (op watter manier dan ook) van God kom, dat "he has in some sense 
a part in its origin, that there is a linkage between the basic mood through which he has communicated with man and the coming into existence of this body of literature"10. Wat is dit anders as om te sê dat die Bybel deur God ingegee is (2 Tim 3:16); of, dat deur die Heilige Gees meegevoer, die mense die Woord wat van God kom, gespreek het (2 Pet 1:21)? Dit is ander woorde en begrippe wat gebruik word, maar basies is dieselfde saak ter sprake: daar word 'n band gelê tussen God se openbaring aan die mense en hierdie geskrifte.

Dit behoort in elk geval duidelik te wees dat die goddelike inspirasie van die Skrif, ook anders gedink kan word as 'n "diktering" of "ingieting" van wat geskryf moet word. Al sou die Bybelboeke uiteindelik niks anders wees as die getuienis van gelowiges nie, is dit nog altyd die getuienis van gelowiges. As sodanig is hierdie getuienis dan van God, want die geloof is van God (2 Kor 4:13; Ef 2:9). Geloof is van God in die sin dat dit volg op die openbaring van God en nie daaraan voorafgaan nie. Die openbaring roep as 't ware die geloof in die lewe. Geloofsgetuienis kan dus nie net mensewerk wees nie. Dit is ten volle mensewerk, want 'n gelowige mens getuig. Dit is egter ook ten volle God se werk, want 'n mens betuig sy geloof, en die geloof is nie sonder God nie.

Wat die inspirasie betref kan nog verwys word na 'n besonder skerpsinnige opmerking van Van Ruler": "De hele openbaring is volledig bemiddeld door mensen. We hebben nooit en nergens puur het eeuwige en naakte Woord van God. Het komt uitsluitend tot ons in de gestalte van doodgewone mensenwoorden. Het wil mij voorkomen, dat dit de blijvende betekenis van de gedachte van de 'inspiratie' is. Zij suggereert dat mensen zijn ingeschakeld." Hierby kan dan nog bygevoeg word - mense met hulle foute en gebreke; foute en gebreke wat ook in die Skrif as sodanig neerslag gevind het.

Hierdie erkenning is nie in stryd met die vasstelling van die belydenis nie. Inteendeel, dit is, in 'n sekere sin van die woord, 'n onderskrywing van die essensie van die belydenis. Die belydenis wil die leer wat in die Heilige Skrif vervat is - die evangeliese waarheid wat daardeur gedra word - veilig stel. Die kritiese wetenskap wil nie iets anders doen nie. Hy eien homself net die reg toe om die Skrif krities te benader, vrae te stel en probleme bloot te lê en aan te toon dat die Skrif nie 'n groot eenheid is waarvan elke onderdeel kan geld as kruisverwysing vir elke ander onderdeel nie. Die wetenskap dui foute in die Skrif aan en maak opmerksaam vir 
vergissings, sonder om egter daarmee die leer wat in die Skrif vervat is, in twyfel te trek. Daar kan bygevoeg word: sonder om ook die gesag van die Skrif in twyfel te trek. Dit is in elk geval die gesindheid van Loader $^{12}$ wat, op voetspoor van Berkhouwer, die kritiese wetenskap aandui as onvermydelik, juis uit respek vir die gesag van die Skrif.

\section{SAMEVATTENDE OPMERKING}

Hierdie kort studie wou aantoon dat, soos die geval met die Bybel, daar minstens twee maniere is waarop die belydenisskrifte hanteer kan word en waarop dit in die kerk kan funksioneer.

Aan die een kant is daar die regoristiese standpunt, wat sy oortuigendste woordvoerders in gereformeerde kringe het, waarvolgens die woorde en nuanses van die belydenisskrif beklee word met 'n ewigheidswaarde en waar hierdie woorde en nuanses gevolglik gesien word as die draers van die waarheid. Aan die ander kant is daar die vryer standpunt, wat daarvoor pleit dat daar gesoek moet word na die wesenlike geloof wat agter die woorde en nuanses verborge is.

Hierdie standpunt spreek van die oortuiging dat die formuleringe, wat meestal die direkte gevolg van polemieke is en gevolglik uiters tendensieus is, nie noodwendig die wesenlike van die belydenis weergee nie en dit selfs kan versluier. Daarom moet die polemiese opsygeskuif, en die wesenlike uitgelig word.

Dié studie was 'n poging om dit te doen. Die resultaat van die ondersoek is dat daar duidelik gestel moet word, dat daar nie noodwendig en vanselfsprekenderwys 'n botsing tussen die belydenisskrif en die kritiese wetenskap sal wees nie. Waar die noodwendigheid van so 'n botsing by voorbaat geproklameer word, getuig dit van ' $n$ interpretasie van die belydenisskrif, wat nie rekening hou met die historiese bepaaldheid daarvan nie.

Voetnote

1. Met instemming aangehaal deur A Noordegraaf, Er staat geschreven, Willem de Zwigjerstichting, 's-Gravenhage, 1969, p 21.

2. Bavinck, H, Gereformeerde Dogmatiek 1/3, Kok, Kampen, 1918, p 462.

3. Polman, ADR, Onze Nederlandsche Geloofsbelijdenis, deel 1, T Wever, Franeker, p 195.

4. Bavinck, 1 c, p 446. 
5. 1 c, p 188-190.

6. $1 \mathrm{c}, \mathrm{p} 222$.

7. Vgl byvoorbeeld

(a) Barr, J, Fundamentalism, SCM Press, London, 1977.

(b) Loader, JA, Ortodokse Fundamentalisme en die gebruik van die Ou Testain Suid-Afrika, Heroormde Teologiese Studies, Jaargang 35, afl 1 en 2.

8. Só Barr, 1 c, pp 209, 217, 219, 239-241; en Berkhouwer, GC, Het Schriftgezag, in De Bijbel in het geding, Callenbach NV, Nijkerk, 1968, p 12.

9. Loader, 1 c p 115.

10. The Bible in the Modern World, SCM Press, London, 1977, p 17.

11. Van Ruler, AA, Schriftgezag en Kerk, in De Bijbel in het geding, p 120.

12. $1 \mathrm{c}, \mathrm{p} 147$. 